\title{
The use of family labor in beef cattle cultivation (case in women farmer groups receiving beef cattle assistance in Bengkulu)
}

\author{
Wahyuni Amelia Wulandari*, Jhon Firison, Zul Efendi, Harwi Kusnadi, and Erpan Ramon \\ Bengkulu Assessment Institute for Agricultural Technology, IAARD, Bengkulu, Indonesia
}

\begin{abstract}
Beef cattle cultivation is a side job for farmers which is carried out by family labor and the incomes are used to finance various needs of the farmers' family. This study aims to determine the use of family labor in beef cattle cultivation and the use of livestock sales. The research was carried out from October 2020 to April 2021 in two Women Farmers Groups (WFG) in Bengkulu City and Seluma Regency who received beef cattle assistance from the government. Data were analyzed descriptively. The results showed that in general, beef cattle cultivation was carried out jointly by man and women farmers with a labor allocation of $39.59 \%$. In intensive farming, farmers are more dominant in cultivation activities amounting to $46.25 \%$, while in semi-intensive farming women farmers are more dominant in cultivation activities $(41.06 \%)$. The income from the sale of livestock are mainly used for children's education expenses and buying vehicles $(91.67 \%$ each), building or renovating houses $(87.50 \%)$, and buying feeder cattle (79.17\%). For the development of beef cattle in farmer group, it is necessary to consider the cultivation system before determining the target of recipient of the program. The development by WFG is more suitable for semiintensive cultivation systems.
\end{abstract}

\section{Introduction}

The maintenance of beef cattle is one of the fields of life to obtain a source of income for rural breeders, breeders still have hopes of the results which aim to meet their daily needs.. Farmers and their families in managing livestock businesses in general also act as workers in the livestock business. The value of this family farmer's workforce cannot be ignored, because labor is one of the production components in raising beef cattle $[1,2,3,4]$.

The workforce in the family consists of breeders, female breeders, and children, where the use of family labor force is not calculated in valued money. The source of labor in the agricultural farming system is the owner of the business and the staff of family members who participate in the farming [5-7]. Female breeders are often neglected as a productive workforce, even though in reality, they are physically involved in the production, processing, and marketing of agricultural products. This is a phenomenon of agricultural business in

* Corresponding author: wahyuniwulandari88@yahoo.co.id 
developing countries, where female breeders are still very limited in access to technological innovation, efficient markets, and mutually beneficial partnership business patterns [8].

Farmers tend to use the labor that comes from families by involving their families such as female breeders and their children in various kinds of beef cattle raising activities. Farmers rarely use wage labor in managing their business, because of the higher cost $[6,8,9]$. The participation of family members in the beef cattle business consists of looking for forage, herding, cleaning the stalls, providing food and drinking [10].

The livestock raising system is divided into 3, namely 1) an extensive farming system: the pen is only used for shelter at certain times (partially functioning), namely at night and at rest. In fact, in this rearing system, sometimes the cage is not available so that the livestock can only take shelter under the trees in the pasture, 2) intensive farming system: livestock are kept continuously in the cage until the time of sale, so cages are an absolute must. All cattle needs are supplied by farmers, including feed and drink. Other activities such as bathing the cows are also carried out in the pen, 3) semi-intensive farming system: semi-intensive cattle rearing is a combination of previous two methods. So, in this semi-intensive cow rearing, there must be a cage and a place for grazing $[11,12]$.

Previous research has shown that the role of women makes a significant contribution to livestock business, from small livestock (poultry) to ruminant livestock business [13-15]. Bengkulu Province Livestock and Animal Health Service has made efforts to assist in the form of brood cattle for WFG which is usually given to livestock groups. Regarding the above background, this study aims to identify the use of family labor in beef cattle cultivation and the use of livestock sales.

\section{Materials and methods}

This research was conducted from October 2020 to April 2021 in two Women Farmers Groups in Bengkulu City and Seluma Regency which received beef cattle assistance from the government through the Bengkulu Province Animal Husbandry and Health Service in 2019. Data collection was carried out through a census of 24 WFG members. The data collected were the characteristics of the respondents, the use of family labor in beef cattle cultivation, and the use of livestock sales. Data were analyzed descriptively.

\section{Result and discussion}

\subsection{Respondent characteristics}

The two WFG located in Bengkulu City and Seluma Regency is quite interesting because even though they are women farmers, they are trusted to receive beef cattle assistance by the local government through the Bengkulu Province Livestock and Animal Health Service. This is due to the persistence of these two WFG in raising beef cattle which can be used as an example for other WFG. The amount of beef cattle assistance to the Rafflesia WFG as many as 10 cows and 1 bull and in the WFG Melati as many as 12 cows and 1 bull. The development of beef cattle in 1.5 years in WFG Melati from 12 cows has given birth to 6 cows and 3 bull, while in WFG Rafflesia has developed into 10 cows and 5 bull, and they have sold their livestock for various purposes. 
Table 1. Characteristics of WFG respondents

\begin{tabular}{|l|c|c|c|}
\hline Description & Range & $\begin{array}{c}\text { Raflesia } \\
\text { WFG }\end{array}$ & Melati WFG \\
\hline Age & $0-14$ & 0 & 0 \\
& $15-64$ & 100 & 100 \\
& $>64$ & 0 & 0 \\
\hline Education & Primary School & 50 & 20 \\
& Junior High School & 50 & 20 \\
& Senior High School & 0 & 60 \\
& Diploma (3 years) & 0 & 0 \\
Number of & Bachelor & 0 & 0 \\
family & $2-4$ & 50 & 80 \\
members & $5-6$ & 50 & 20 \\
\hline Cattle & $>6$ & 7 & 0 \\
raising & Other people raise cattle & 88 & 0 \\
management & Relf-maintained & 86 & 22 \\
& cattle & 0 & 78 \\
\hline Number of & $1-2$ & 7 & 40 \\
cattle & $3-5$ & 14 & 50 \\
& $6-10$ & 29 & 10 \\
& $11-20$ & 36 & 0 \\
\hline Farming & $>20$ & 21 & 90 \\
experience & $0-5$ & 71 & 10 \\
(years) & $6-10$ & 8 & 0 \\
\hline Maintenance & $>10$ & 7 & 90 \\
system & Intersive & 10 \\
& Semi intensive & & 0 \\
\hline
\end{tabular}

Source: * interviews with various informants

The beef cattle business is for breeding and fattening purposes. Breeding efforts to increase population and provide feed for fattening. The beef cattle business carried out by female farmers in both WFGs is a part of community life that is socially and culturally integrated. Cows are used as savings because by raising cows to be used when farmers feel they need urgent funds so that at that time the cows will be sold.

Characteristics of respondent from 2 WFG recipients of beef cattle assistance from the Bengkulu Province Animal Husbandry and Health Service in 2019 had a productive age in the range of 15 - 64 years (Table 1). The level of education is classified as low at WFG Rafflesia because respondents only received the highest education only at the junior high school level (50\%) and the rest received elementary education (50\%), while WFG Melati had higher education levels, namely high school $(60 \%)$ and the rest respectively. $-20 \%$ each have elementary and junior high school education [16].

The number of family members is classified as small to moderate, namely, 2-4 people $(50 \%)$ and $4-6$ people $(50 \%)$ in WFG Rafflesia, while at WFG Melati the number of family members is even less, namely between $2-4$ people (80\%) and the remaining 5-6 people $(20 \%)$. Most of the cattle kept were noisy in both WFGs. While the number of livestock kept by WFG Rafflesia is more, namely 3-> 20 heads compared to WFG Melati which is only 1-10 heads.

The pattern of raising livestock is different in the two WFGs where WFG Rafflesia applies a semi-intensive farming pattern, namely, livestock are grazed under oil palm trees while in WFG Melati, livestock is maintained intensively, namely continuously in the pen and only occasionally removed from the cage. Based on the experience of raising WFG 
Rafflesia, it has a longer experience farming than WFG Melati. The semi-intensive farming system allows WFG to raise livestock in large numbers and take place continuously.

\subsection{Utilization of family labor force in beef cattle farming}

Most of the workers in the livestock business come from families consisting of the father as the head of the family, the mother, and the children. According to [17] in general, the use of working hours is considered to meet the needs, regardless of work habits, namely eight hours of work in one working day. The utilization of family labor in beef cattle cultivation is carried out jointly between the father and mother. The role in beef cattle farming that is done by the father alone is $32.81 \%$ higher than the role of the mother $(22.41 \%)$, while the joint role performed by the father and mother is even higher $(39.59 \%)$. The father's role is dominant in bathing cattle, looking for grass, taking care of cattle mating (AI and natural mating) while the mother's role is dominant to take care of AI. The joint role between father and mother is dominant when building cages, cleaning cages, looking for grass, providing food and water, and health care in Fig. 1. This is according to opinion [18] that generally the labor devoted to the beef cattle business is from the family. Breeders tend to use labor from families by involving their families such as their wives and children in various kinds of beef cattle rearing activities, breeders rarely use hired labor in managing their business, because it results in higher costs.

According to [19] the participation of family members in the beef cattle business consists of looking for forage, herding, cleaning the cage, providing feed, and drinking. The amount of working hours per day devoted by household members in livestock business ranges from 4 hours per day, where the average working time of men is about 1.9 hours/day, women 1.2 hours/day, children 1.1 hours/day with a total of 4.29 . The average working time of men is relatively higher than that of women and children, while the amount of time that women work is higher than that of children.

In WFG Melati, with the labor-intensive livestock rearing pattern, the father is dominantly involved. The role of the father is $46.25 \%$, the role of the mother is $11.25 \%$, the role of the father and mother (together) is $42.50 \%$. The father's role is dominant in making cages, bathing cattle, and natural mating, while the mother's role is dominant in taking care of AI. The joint roles performed by the father and mother were dominant when building the cage, cleaning the cage, looking for grass, providing food and water, health care in Fig. 1. Based on this, at WFG Melati, mothers have less role in beef cattle cultivation because many activities are done by fathers.

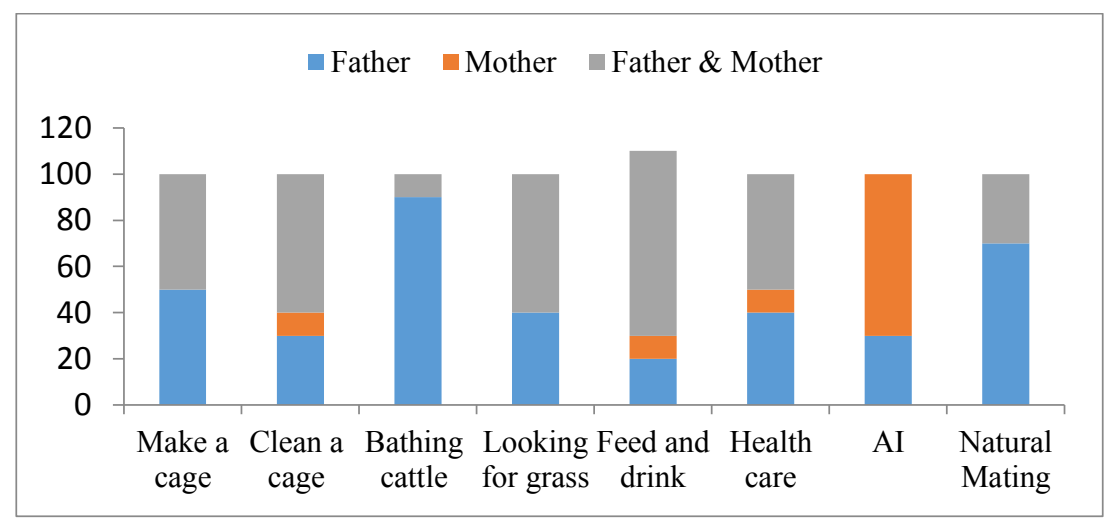

Fig. 1. Utilization of family labor in beef cattle cultivation at WFG Melati 
In WFG Rafflesia with a semi-intensive livestock rearing pattern where livestock is grazed on oil palm plantations and field land in the morning to evening while at night the cattle are caged behind the house, the dominant labor involved is mother. The role of father is very small, only $16.96 \%$, while the role of the mother is $41.06 \%$, while the role that is carried out jointly between the father and mother is $33.04 \%$. The role of the father is dominant in the implementation of AI, where the father contacts the inseminator and assists in the implementation of AI, while the role of the mother is dominant in cleaning the cage, looking for feed to grazing fields and oil palm plantations, providing food and water in the cage, and implementing natural mating. The roles played by fathers and mothers are dominant when making cages, health care, and natural mating in Fig. 2

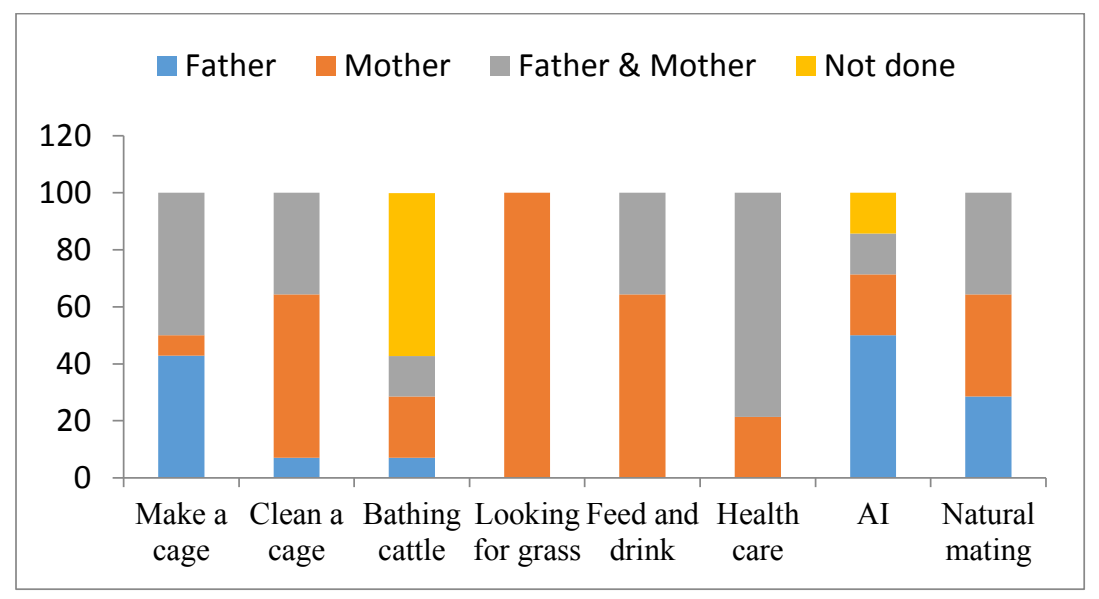

Fig. 2. Utilization of family labor in beef cattle cultivation at WFG Raflesia

WFG Rafflesia is involved more in cattle cultivation than WFG Melati because in semiintensive farming (looking for grass, no need to build permanent cages) WFG can relatively do it easily.

\subsection{Utilization of livestock sales}

The marketing or selling business of beef cattle is mostly controlled by marketing institutions that have large business capital such as blantik, traders, and butchers. Each marketing channel has its role and function in the marketing process. The beef cattle marketing business is mostly controlled by intermediary traders. The existence of intermediary traders on the other hand is very helpful for farmers in marketing their livestock and making it easier for farmers. So far, there have been no obstacles for farmers to market their livestock products.

There are 8 benefits from the sale of beef cattle for members of WFG Rafflesia in Fig. 3. Aspects of the benefits of beef cattle business for families of WFG Rafflesia members from sales profits are utilized with the highest priority for buying a vehicle and the cost of building a house while the lowest priority is for Hajj savings. Based on Fig. 3 the priority scale was chosen for individual WFG members from the proceeds of livestock sales in a row from the highest to the lowest, namely buying a vehicle and the cost of building/renovating a house $(92.86 \%)$, savings, and school fees $(85.71 \%)$, buy cows $(78.57 \%)$, buy gold $(42.86 \%)$, buy gardens/land $(28.57 \%)$, and hajj savings $(7.14 \%)$. According to respondents, 
the order of priority is a primary need to support the beef cattle business and survival for members of WFG Rafflesia in Bengkulu City.

There are also 8 benefits from the sale of beef cattle for WFG Melati members in Fig. 4. Aspects of the benefits of the beef cattle business for WFG Melati members from the profit from selling beef cattle are utilized with the highest priority for savings and education costs while the lowest priority is for the annual pilgrimage. Based on Fig. 4 the priority scale chosen for individual WFG members from the results of livestock sales, from the highest to the lowest, namely savings and education costs (100\%), buying land/gardens and buying vehicles (90\%), building houses, buy feeder cattle, buy gold and hajj savings $(80 \%)$. According to the respondent, the priority order is the primary need to support the beef cattle business and help meet the family needs of WFG Melati members in Seluma Regency. According to [20], the contribution of beef cattle income to farmer households ranges from $15 \%$ to $26 \%$. The area of agricultural land owned hurts the contribution of beef cattle income to household farming.

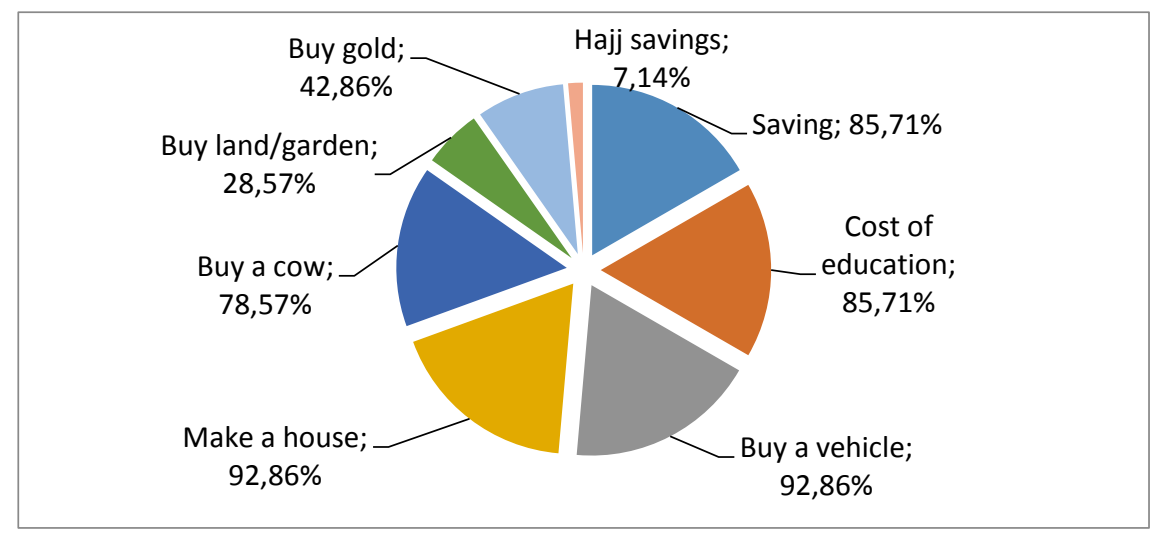

Fig. 3. Utilization of livestock sales at WFG Raflesia (semi-intensive farming system)

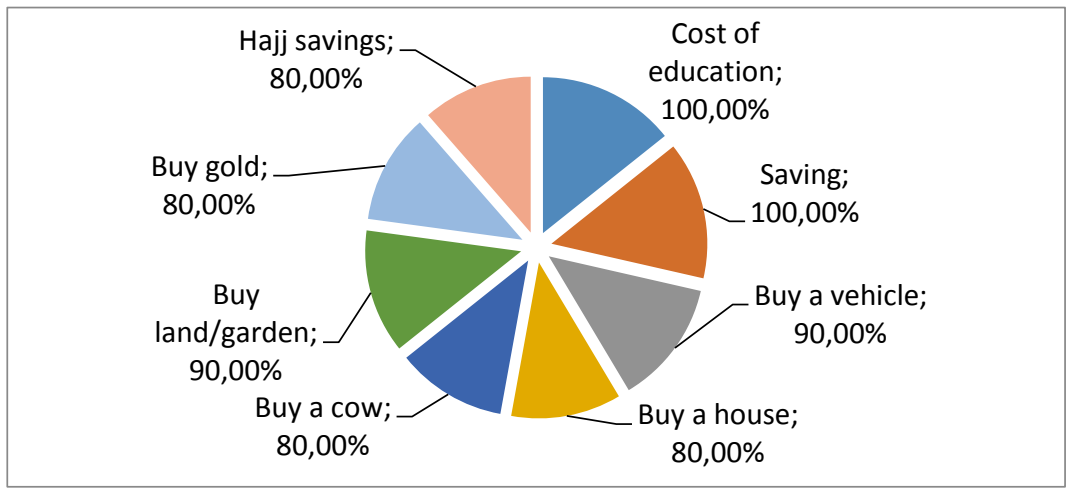

Fig. 4. Utilization of WFG Melati (intensive farming system)

The use of the proceeds from the sale of livestock at the WFG Melati and the Rafflesia WFG of the highest priority is used for the cost of children's education and buying a vehicle (91.67\% respectively), building or renovating a house $(87.50 \%)$, and buying feeder cattle (79.17\%) in Fig. 5. 


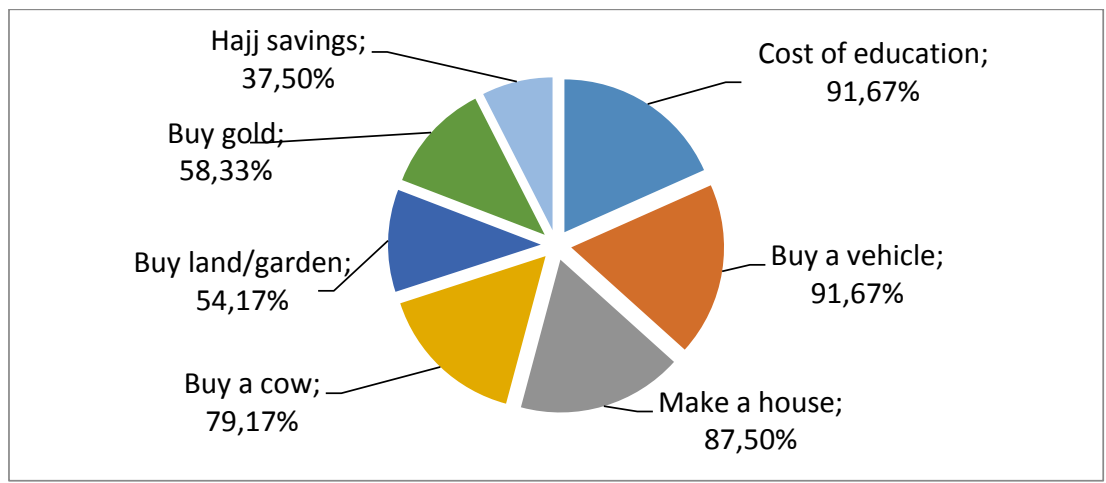

Fig. 5. Utilization of livestock sales in both WFG

\section{Conclusions}

The results showed that in general beef cattle cultivation was carried out jointly by breeders and female breeders with a workforce allocation of $39.59 \%$. In intensive farming, farmers are more dominant in allocating labor for cultivation activities by $46.25 \%$, while in semiintensive farming women farmers are more dominant in cultivation activities, namely $41.06 \%$. The proceeds from the sale of livestock are mainly used for the cost of children's education and buying vehicles $(91.67 \%$ respectively), building or renovating houses $(87.50 \%)$, and buying feeder cattle $(79.17 \%)$. Provision of beef cattle assistance to WFG is more effective if it is given to WFG with a semi-intensive farming pattern because female farmers find it difficult to find grass if it is maintained intensively. With a semi-intensive farming system, women farmers can raise more cows because they do not need to look for grass but only bring their cows to grazing fields in oil palm plantations to find the food.

\section{References}

1. D. Darmawi. Jurnal Ilmu-Ilmu Peternakan 14 (2011).

2. Z. Dady, C.L. Kaunang, Y.L.R. Tulung. Agri Sosio Ekonomi Unsrat 14, 1 (2018).

3. Hajirin, M. Hubeis and Suryahadi 15 (2020).

4. N.D Wahyono. Disertasi (2017).

5. E. Garner and A. P de la O Campos. Identifying the "family farm": an informal discussion of the concepts and definitions (ESA Working Paper, Rome, 2014).

6. E. M. V Bettencourt, M. Tilman, V. Narciso, M. L da Silva Carvalho, P. S. de Sousa Hendriques. 53, 1 (2015)

7. KIT, Agri-ProFocus and IIRR. Challenging chains to change: Gender equity in agricultural value chain development (KIT Publishers, Royal Tropical Institute, Amsterdam, 2012).

8. H. Tian, C. Lu, J. Yang, K. Banger, D. N. Huntzinger, C. R. Schwalm, A. M. Michalak, The role of women in agriculture 29 (2015).

9. G. Rapsomanikis, The economic lives of smallholder farmers FAO Food Agric. Organ. United Nations 39 (2015).

10. U. Santoso and Kususiyah, J. Sain Peternakan Indonesia, 10, 1 (2015).

11. A.P.J. Watts, R.J. Davis, O.B. Keane, M.M. Luttrell, R.W. Tucker, R. Stafford and S. Janke, Beef cattle feedlots : design and construction (Meat \& Livestock Australia Ltd, Australia, 2015). 
12. D. B. Wiyono and Aryogi, Sistem Perbibitan Sapi Potong (Pusat Penelitian dan Pengembangan Peternakan, Bogor, 2007).

13. S. Mastuti and N. Hidayat. J Animal Production, 11, 1 (2009).

14. U. P. Astuti, E. Makruf and A. Ishak. Analisis peran wanita dalam rumah tangga petani mendukung keberhasilan program SLPTT - PUAP di Bengkulu [Internet] in http://bengkulu.litbang.pertanian.go.id/ind/ima ges/dokumen/publikasi/Semnas\%20Medan.

15. Kasmiyati and A. Priyanti. Peranan dan alokasi waktu tenaga kerja perempuan dalam usaha ternak sapi potong di Jawa Timur in Prosiding Seminar Nasional Teknologi Peternakan dan Veteriner Tahun 2014, 12 - 14 Agustus 2014, Malang, Indonesia (2014).

16. S. Baco, R. Malaka, M. Hatta, and Zulkharnain. Pre-weaning performances and mortality rate of calf Bali cattle maintened in the community with smallholder and intensive system in Proceeding of the $1^{\text {st }}$ International Conference of Animal Science and Technology, ICAST, 6 - 7 May 2018, Makassar, Indonesia (2018).

17. Soekartawi, A. Soeharjo,., J.L. Dillon, and J.B. Hardeker. I lmu usaha tani dan pengembangan petani kecil (Universitas Indonesia Press, Jakarta, 1986).

18. M. Handayani, S. Gayatri, and B. Mulyanto. Jurnal Ilmu-Ilmu Pertanian. 1, 2 (2005).

19. R. Hendayana and MH. Togatorop. JITV 19, 3 (2014).

20. B. Hartono and E. S. Rohaeni, J. Livestock Research for Rural Development, 26, 8 (2014). 